\title{
PENGARUH PENGUNYAHAN PERMEN KARET YANG MENGANDUNG XYLITOL TERHADAP PENURUNAN INDEKS PLAK PADA PEROKOK
}

\author{
Popy Sandra ${ }^{1}$, Yustini Allioes ${ }^{2}$, Susi $^{3}$ \\ ${ }^{1}$ Mahasiswa Fakultas Kedokteran Gigi Universitas Andalas \\ ${ }^{2}$ Staf Pengajar Fakultas Kedokteran Universitas Andalas \\ ${ }^{3}$ Staf Pengajar Fakultas Kedokteran Gigi Universitas Andalas
}

\begin{abstract}
Dental plaque plays main important role in cause of caries and periodontal disease. The one of control is to chewing gum containing xylitol. The aim of the study was to evaluate the effect of chewing gum containing xylitol in reducing the plaque index scores in smoker. The method of this study was quasi experiment with pretest-posttest design involved smoker sample total 35 people. Examination plaque index score was conducted over 2 days using PHP-M plaque index. Data analysis is conducted using Paired t-test. Average plaque index prior to chewing gum containing xylitol is 37,9714 $\pm 8,62106$ and average plaque index after to chewing gum containing xylitol is15,2000 44,96340 . After chewing, it shows that mean percentage plaque index prior and after is $22,77143 \pm 9,49330$ with $p<0,05$. So, chewing gum containing xylitol are equally effective reducing the plaque index scores in smoker.
\end{abstract}

Keywords : Chewing gum containing xylitol, plaque index, smoker.

Affiliasi penulis : 1. Fakultas Kedokteran Gigi Universitas Andalas Korespondensi : Popy Sandra, email: Sandrapopy31@yahoo.com

\section{PENDAHULUAN}

Kesehatan gigi dan mulut merupakan bagiandari kesehatan tubuh secara umum. Kesehatan gigi dan mulut tidak hanya terkait dengan persoalan estetika, tetapi juga dapat menimbulkan masalah kesehatan yang serius apabila seseorang mengabaikan kebersihan rongga mulutnya.

Plak gigi memegang peranan penting dalam menyebabkan terjadinya masalah kesehatan gigi dan mulut. ${ }^{1}$

Plak gigi merupakan deposit lunak yang berwarna putih keabu-abuan atau kuning yang melekat erat pada permukaan gigi. ${ }^{2,3}$ Akumulasi plak gigi yang banyak mengandung mikroorganisme patogen merupakan penyebab utama timbulnya penyakit pada jaringan keras gigi maupun jaringan pendukung gigi. ${ }^{1,4}$ Penyakit pada jaringan keras gigi berupa karies gigi dan penyakit pada jaringan pendukung gigi berupa penyakit periodontal merupakan penyakit terbanyak yang disebabkan oleh plak $^{3}$

Prevalensi masalah kesehatan gigi dan mulut penduduk Indonesia adalah 25,9\% dan masalah kesehatan gigi dan mulut di wilayah Sumatra Barat cukup 
tinggi yaitu 22,2\%. Indeks DMF-T pada wilayah Sumatra Barat sebesar 4,7 dengan nilai masing-masing: $\mathrm{D}-\mathrm{T}=1,7 ; \mathrm{M}-\mathrm{T}=3,1$; $\mathrm{F}-\mathrm{T}=0,06.5$ Hasil Survei Kesehatan Rumah Tangga (SKRT) tahun 2010, menunjukan bahwa penyakit periodontal termasuk dalam 10 besar penyakit yang dialami masyarakat Indonesia dengan persentase $8,7 \%$ dan hanya $3,2 \%$ masyarakat yang melakukan pengobatan periodontal. $^{6}$

Kontrol plak merupakan upaya meningkatkan kebersihan mulut untuk menghindari resiko terjadinya karies gigi dan penyakit periodontal. Kontrol plak dapat dilakukan secara mekanis, secara kimiawi dan diet sukrosa. ${ }^{7}$ Menyikat gigi dan menggunakan dental floss merupakan cara mekanis yang efektif dalam mengendalikan plak, mencegah dan mengendalikan karies dan penyakit periodontal. ${ }^{7,8}$

Kontrol plak secara mekanis dapat dilengkapidengan kontrol plak secara kimiawi dengan menggunakan obat kumur yang mengandung antibotik maupun senyawa kimia lain yang merupakan perawatan tambahan setelah menyikat gigi. Kontrol plak secara kimiawi mampu menghilangkan sisa-sisa makanan dan bakteri yang tertinggal di dalam rongga mulut $^{7}$

Pembentukan plak juga dapat dikontroldengan membatasi konsumsi makanan yang mengandung karbohidrat yang menjadi sumber energy utama bakteri. $^{3}$ Karbohidrat berupa sukrosa terbukti sebagai bahan utama pembentuk matriks dalam plak dan sebagai sumber energi bakteri dalam membentuk plak. Plak bisa dikontrol dengan mengganti konsumsi sukrosa dengan pemanis buatan lainnya yang dapat mengurangi jumlah bakteri rongga mulut salah satunya jenis xylitol. ${ }^{3,9}$

Xylitol merupakan gula alkohol dengan lima rantai karbon yang bersifat antimikrobial. Bakteri utama yang terdapat pada plak seperti Streptococcus mutans tidak mampu memfermentasi gula dengan lima rantai karbon sebagai zat energi. ${ }^{10}$ Hal ini menyebabkan melemahnya kemampuan bakteri untuk melekat ke permukaan gigi dan tidak punya energi memproduksi polisakarida ekstraselular yang digunakan dalam pembentukan plak. ${ }^{11,12,13}$ Rasa manis dari xylitol mampu merangsang kelenjar saliva untuk menstimulasi laju aliran saliva yang dapat meningkatkan pembersihan rongga mulut. $^{3,9}$ 
Kontrol plak secara mekanis, kimiawi dan dietbisa didapatkan dengan mengunyah permen karet yang mengandung xylitol. Mengunyah permen karet memberikan stimulus mekanis dan kimiawi terhadap kelenjar saliva. Stimulus mekanis berupa pengunyahan permen dapat merangsang peningkatan sekresi saliva dan stimulus kimiawi berupa rasa manis dari permen karet juga dapat meningkatkan sekresi saliva. ${ }^{14,15}$ Terjadinya peningkatan sekresi saliva menimbulkan peningkatan jumlah volume saliva sehingga konsistensi saliva menjadi lebih encer yang akan menyebabkan terjadinya pembesihan rongga mulut (self cleansing). Peningkatan sekresi saliva juga meningkatkan jumlah dan susunan kandungan saliva, seperti bikarbonat yang dapat meningkatkan Ph. $^{14}$ Mengkonsumsi permen karet mengenai seluruh permukaan gigi akan menghasilkan efek pembersihan pada permukaan gigi dari sisa makanan dan plak. $^{8}$ Pemberian permen karet xylitol 3 sampai 5 kali sehari dikunyah minimal selama 5 menit setelah makan dapat menghambat akumulasi plak dan demineralisasi enamel, meningkatkan remineralisasi pada karies awal dan mengurangi jumlah Streptococcus mutans. ${ }^{15}$ Dosis efektif untuk menurunkan akumulasi plak dan meningkatkan buffer saliva yaitu mengkonsumsi xylitol sebagai pengganti gula yaitu 5-10 gram per hari. ${ }^{11}$

Perokok mempunyai skor plak dan kalkuluslebih besar bila dibandingkan dengan yang bukan perokok. ${ }^{16}$ Rokok mengandung berbagai bahan kimia berbahaya salah satunya adalah tar yang dapat mengendap pada permukaan gigi dan akar gigi menimbulkan noda dan perubahan warna (stain) pada gigi, gigi palsu dan restorasi menyebabkan permukaan ini menjadi kasar dan mudah ditempeli oleh sisa makanan dan bakteri yang akhirnya membentuk plak..$^{3,17,18}$ Berdasarkan penjelasan diatas, peneliti tertarik untuk mengetahui pengaruh penggunaan permen karet yang mengandung xylitol terhadap penurunan indeks plak pada perokok.

\section{METODE}

Penelitian ini bertujuan untuk untuk mengetahui pengaruh pengunyahan permen karet yang mengandung xylitol terhadap penurunan indeks plak pada perokok. Penelitian ini merupakan penelitian yang bersifat eksperimen semu (quasi experimental) dengan pre-post design pada bulan November 2014 hingga bulan Januari 2015. Sampel 
dalam penelitian ini adalah karyawan dan buruh yang bekerja di PT Astra Internasional Auto 2000 Tbk cabang Bypass Padang yang memenuhi kriteria inklusi dan kriteria eksklusi.

Kriteria inklusi:

a. Berusia 20-35 tahun

b. Keadaan kesehatan umum baik

c. Lama merokok $\geq 5$ tahun

d. Perokok berjenis kelamin laki-laki

e. Jenis rokok yang digunakan yaitu rokok kretek

f. Responden mengkonsumsi $\geq 10$ batang per hari

Kriteria ekslusi:

a. Telah dilakukan skeling $<6$ bulan

b. Menggunakan alat ortodonti cekat

c. Terdapat karies gigi pada gigi yang dibutuhkan

d. Menggunakan protesa gigi lepasan

Metode pengambilan sampel dalam penelitian ini adalah dengan purposive sampling dan jumlah sampel keseluruhan adalah 35 orang yang terdiri dari kelompok perlakuan.

Pengumpulan data untuk memenuhi kriteria inklusi dan ekslusi sampel dilakukan pada hari kerja dengan menyebar kuesioner, wawancara dan pemeriksaan rongga mulut. Sebelum hari penelitian, peneliti menjelaskan dan memberikan simulasi mengenai cara menyikat gigi dengan menggunakan metode Bass dan subjek penelitian mempraktekkan dirumah pada malam hari sebelum tidur. Subjek penelitian diinstruksikan tidak melakukan penyikatan gigi dan tidak mengkonsumsi makanan dan minuman apapun pada pagi hari kecuali air putih pada 2 hari penelitian. Pagi hari subjek penelitian hanya diperbolehkan berkumur.

Penelitian dilakukan selama 2 hari yaitu tanggal 27-28 Januari 2015, pada hari pertama dilakukan pemeriksaan nilai indeks plak awal (pretest) sebelum mengunyah permen karet yang mengandung xylitol dengan menggunakan pengukuran indeks plak PHP-M (Metode Personal Performance Modified Index). Selanjutnya subjek penelitian diberikan makanan yang telah disediakan dan 20 menit setelah makan subjek melakukan sikat gigi bersama menggunakan teknik Bass. Subjek penelitian diberikan 6 butir permen karet yang mengandung xylitol yang masing-masing permen karet dikonsumsi pada jumlah dan waktu tertentu, yaitu 2 butir permen dikunyah selama 5 menit pada pukul 08.00 WIB, 13.30 WIB, dan pukul 19.00 WIB (setelah makan) dengan mengenai seluruh 
bagian gigi dan mulut yang ada di sisi kanan dan kiri mulut dan tidak melakukan tindakan kebersihan mulut baik secara mekanis maupun kimiawi pada pukul 08.00-19.00 WIB, kecuali penyikatan gigi pada malam hari sebelum tidur. Hari kedua penelitian, dilakukan pengukuran nilai indeks plak setelah subjek penelitian setelah mengunyah permen karet pada hari sebelumnya (posttest). Setelah mendapatkan data skor plak sebelum dan sesudah mengunyah permen karet xylitol, semua hasil pretest dan posttest pada kedua kelompok subjek dicatat pada lembar pemeriksaan skor indeks plak.

\section{HASIL}

\section{Indeks Plak Sebelum dan Sesudah Mengunyah Permen Karet yang \\ Mengandung Xylitol}

Tabel 1 Tabel Perbedaan Kategori Hasil Pengukuran Indeks Plak Sebelum dan Sesudah Mengunyah Permen Karet Mengandung Xylitol pada Perokok

\begin{tabular}{|c|c|c|c|c|c|c|c|c|c|}
\hline \multirow{3}{*}{$\begin{array}{c}\text { Indeks } \\
\text { Plak }\end{array}$} & \multicolumn{6}{|c|}{ Kategori Skor Plak } & \multirow{2}{*}{\multicolumn{2}{|c|}{ Total }} & \multirow{3}{*}{$\mathrm{P}$} \\
\hline & \multicolumn{2}{|c|}{$\begin{array}{c}\text { Baik } \\
\text { (Skor 0- } \\
20) \\
\end{array}$} & \multicolumn{2}{|c|}{$\begin{array}{c}\text { Sedang } \\
\text { ( Skor } \\
21-40) \\
\end{array}$} & \multicolumn{2}{|c|}{$\begin{array}{c}\text { Buruk } \\
\text { ( Skor } \\
41-60) \\
\end{array}$} & & & \\
\hline & $\mathrm{n}$ & $\%$ & $\mathrm{n}$ & $\%$ & $\mathrm{n}$ & $\%$ & $\mathrm{n}$ & $\%$ & \\
\hline Pretest & 2 & 5.7 & 16 & 45.7 & 17 & 48.6 & 35 & 100 & .000 \\
\hline Posttest & 30 & 85.7 & 5 & 14.3 & - & - & 35 & 100 & \\
\hline
\end{tabular}

Pada tabel 1 hasil penelitian menunjukkan dari 35 sampel sebelum perlakuan (pretest) terdapat 2 sampel dengan skor indeks plak termasuk dalam kategori skor plak baik (skor diantara 0-20) dengan persentase 5.7\%, dan 17 sampel dalam kategori skor plak buruk (skor diantara 41-60) dengan persentase $48.6 \%$. Sedangkan setelah perlakuan (posttest) terdapat 30 sampel dengan skor indeks plak termasuk dalam kategori skor plak baik dengan persentase $85.7 \%$, dan tidak ditemukan sampel dengan skor indeks plak buruk pada kelompok posttest.

Tabel 2 Hasil Pengukuran Indeks Plak Sebelum dan Sesudah Mengunyah Permen Karet Mengandung Xylitol pada Perokok

\begin{tabular}{cccccc}
\hline Indeks & \multicolumn{5}{c}{ Indeks plak } \\
\cline { 2 - 6 } Plak & $\mathrm{N}$ & Rata-rata & SD & Minimum & Maksimum \\
& & & & & \\
Sebelum & 35 & 37.9714 & 8.62106 & 18.00 & 52.00 \\
Sesudah & 35 & 15.2000 & 4.96340 & 7.00 & 25.00 \\
\hline
\end{tabular}

Pada tabel 2 hasil penelitian menunjukkan rata-rata indeks plak sebelum mengunyah permen karet yang mengandung xylitol dari 35 orang subjek penelitian adalah $37.9714 \pm 8.62106$. Nilai indeks plak terendah adalah 18.00 dan nilai indeks plak tertinggi adalah 52.00. Dari hasil penelitian rata-rata indeks plak sesudah mengunyah permen karet yang mengandung xylitol dari 35 orang subjek penelitian adalah 15.2000 \pm 4.96340 . Nilai indeks plak 
terendah adalah 7.00 dan nilai indeks plak tertinggi adalah 25.00.

Perbedaan Skor Indeks Plak Sebelum dan Sesudah Mengunyah Permen Karet yang Mengandung Xylitol (Paired T-test)

Tabel 3 Selisih rata-rata penurunan nilai Indeks plak sebelum dan sesudah mengunyah permen karet yang mengandung xylitol

\begin{tabular}{cccccc}
\hline Variabel & $\mathrm{N}$ & $\begin{array}{c}\text { Rata- } \\
\text { rata } \pm\end{array}$ & & IK 95\% & $\mathrm{p}$ \\
\cline { 4 - 5 } & & SD & & \\
\cline { 4 - 5 } & & & Upper & Lower & \\
\hline Selisih & & & & & \\
indeks & 35 & 22.771 & 19.51037 & 26.03249 & .000 \\
plak & & $43 \pm$ & & & \\
pretest & & 9.4933 & & & \\
dan & & 0 & & & \\
posttest & & & & & \\
& & & & & \\
\hline
\end{tabular}

Hasil uji "Paired t-test" menunjukkan nilai $\mathrm{p}=0,000$ sehingga didapatkan nilai $\mathrm{p}<0,05$ yang berarti terdapat perbedaan yang bermakna dari selisih rata-rata kelompok eksperimen yang mengunyah permen karet yang mengandung xylitol.

\section{PEMBAHASAN}

Dari 35 sampel perokok, hampir setengah dari subjek penelitian (yaitu 48.6\%) berada dalam kategori skor plak buruk (41-60). Hal ini disebabkan karena menyikat gigi yang dalam prosedur penelitian dilakukan pada malam hari sebelum hari penelitian tidak dilakukan dengan cara yang baik dan benar walaupun dengan metoda yang sama, dan menyikat gigi saja tidak efektif membersihkan semua plak gigi terutama oleh perokok. ${ }^{19}$

Merokok dapat mengakibatkan status kebersihan mulut seorang individu menjadi buruk. Jumlah kalkulus pada perokok cenderung lebih banyak daripada yang bukan perokok memudahkan penempelan plak pada permukaan kalkulus yang kasar sehingga merupakan faktor pendukung terjadinya penyakit periodontal. ${ }^{16}$ Rokok kretek yang digunakan oleh subjek penelitian merupakan jenis rokok yang mempunyai kadar tar dan nikotin lebih tinggi yaitu $20 \mathrm{mg}$ tar dan 4-5 mg nikotin dari pada rokok putih yaitu 14-15 mg tar dan $5 \mathrm{mg}$ nikotin. Tar yang terkandung dalam rokok dapat menyebabkan terbentuknya stain yang mempunyai permukaan yang kasar sehingga mudah ditempeli oleh sisa makanan dan kuman yang akhirnya membentuk plak. Selain itu, akumulasi plak pada permukaan gigi yang kasar sulit dibersihkan dibandingkan dengan plak pada permukaan gigi yang licin, sehingga ditemukan akumulasi plak yang lebih banyak pada perokok. ${ }^{17}$

Pemeriksaan indeks plak akhir (posttest) dilakukan pada hari berikutnya 
setelah pada hari pertama dilakukan perlakuan mengunyah permen karet yang mengandung xylitol. Hasil pemeriksaan skor indeks plak sesudah mengunyah permen karet yang mengandung xylitol adalah 15.2000, yaitu kurang dari setengah permukaan gigi indeks ditemukan akumulasi plak. Dari 35 sampel perokok terdapat 30 sampel dengan skor indeks plak dalam kategori baik dan tidak ditemukan sampel dengan skor indeks plak buruk pada kelompok posttest. Penurunan skor indeks plak pada posttest ini disebabkan kelompok posttest pada hari sebelumnya mengkonsumsi permen karet, dimana gerakan pengunyahan permen karet dapat meningkatkan aliran saliva dalam rongga mulut. Sebagian besar produk saliva yaitu sekitar 90\% dihasilkan saat mengunyah dan makan yang merupakan reaksi rangsangan yang berupa pengecapan dan pengunyahan makanan. $^{20}$ Mengunyah permen karet memberikan stimulus mekanis dan kimiawi terhadap kelenjar saliva. Stimulus mekanis berupa pengunyahan permen dapat merangsang peningkatan sekresi saliva dan stimulus kimiawi berupa rasa manis dari permen karet juga dapat meningkatkan sekresi saliva. ${ }^{14}$
Peningkatan sekresi saliva menyebabkan terjadinya peningkatan jumlah volume saliva membuat konsentrasi saliva menjadi lebih encer yang mendukung terjadinya pembesihan rongga mulut (self cleansing) dari gula dan asam dari gigi. Dengan meningkatnya laju aliran saliva, dapat menetralkan asam yang dihasilkan oleh bakteri plak, maka selama mengunyah derajat keasaman saliva menjadi naik. Peningkatan sekresi saliva juga meningkatkan jumlah dan susunan kandungan saliva seperti konsentrasi bikarbonat yang sangat berperan dalam buffer saliva, fosfat dan kalsium. ${ }^{21}$ Perubahan dari komposisi ini mestimulasi peningkatan kemampuan saliva untuk mencegah penurunan $\mathrm{pH}$, lingkungan rongga mulut yang tidak asam menjadikan situasi yang tidak nyaman untuk bakteri berkembang biak. Selain itu, peningkatan produksi saliva dapat mengurangi endapan sisa makanan di permukaan gigi. ${ }^{22}$

Mengkonsumsi permen karet diinstruksikan dikunyah mengenai seluruh permukaan gigi setelah makan dapat menghasilkan efek pembersihan pada permukaan gigi sehingga dapat meningkatkan kebersihan dari plak. $^{3}$ Adanya perubahaan kebiasaan subjek 
penelitian dalam menyikat gigi menjadi lebih baik, akibat memahami akan diperiksa pada hari selanjutnya dapat menjadi faktor yang mempengaruhi penurunan skor indeks plak.

Jenis permen karet yang digunakan yaitupermen karet yang mengandung xylitol. Xylitol merupakan jenis gula yang tidak bisa difermentasi oleh sebagian besar bakteri penghasil plak dan dapat menghambat produksi asam. Tidak seperti gula lainnya yang terdiri dari 6 rantai karbon, pemanis xylitol terdiri lima rantai karbon dan lima gugus hidroksil yang sangat sulit difermentasi oleh bakteri menjadi energi. ${ }^{23}$ Hal ini mengakibatkan melemahnya kemampuan bakteri untuk melekat ke permukaan gigi dan tidak punya energi memproduksi polisakarida ekstraselular yang digunakan dalam pembentukan plak, tidak ada energi yang dihasilkan mengakibatkan bakteri sulit bertahan sehingga didapatkan penurunan jumlah penumpukan plak pada permukaan gigi. $^{12,13}$

Hasil penelitian yang dilakukan terhadap 35 sampel perokok di kantor Perusahaan Otomotif PT Astra Internasional Auto 2000 Tbk cabang Bypass Padang, terdapat perbedaan ratarata selisih skor indeks plak kelompok perlakuan pretest dan posttest mengunyah permen karet yang mengandung xylitol yang didukung oleh uji statistik menggunakan "paired t-test" adalah $22,77143 \pm 9,49330$ dan didapatkan nilai $\mathrm{p}<0,05$ yang berarti terdapat perbedaan yang bermakna terhadap rata-rata indeks plak sebelum dan sesudah perlakuan mengunyah permen karet yang mengandung xylitol.

Hasil penelitian menunjukkan bahwa mengunyah permen karet mengandung xylitol efektif dalam membantu penurunan nilai indeks plak. Mekanisme penurunan indeks plak pada penelitian ini merupakan kombinasi dari efek pengunyahan permen karet yang efektif dalam merangsang laju aliran saliva sehingga meningkatkan $\mathrm{Ph}$ dan pembersihan rongga mulut, serta efek xylitol yang terkandung dalam permen karet sebagai bahan pengganti gula. ${ }^{11,14}$

Dengan demikian, permen karet yang mengandung 1,242 gram xylitol, dua butir tiga kali sehari dikunyah minimal selama 5 menit yang dikomsumsi pada jam pukul 08.00 WIB, 13.30 WIB, dan pukul 19.00 WIB setelah makan makanan yang mengandung karbohidrat, mempunyai efek menurunkan skor plak. ${ }^{11}$ Penurunan skor indeks plak pada hasil 
penelitian ini sesuai dengan penelitian yang dilakukan oleh Putti (2008) yang melakukan penelitian kepada kelompok sampel xylitol dan hasilnya terjadi penurunan indek plak pada responden yang mengkonsumsi permen karet yang mengandung xylitol yang diberikan 3 kali dalam waktu yang ditentukan. ${ }^{8}$

Uji klinis yang dilakukan oleh European FoodSafety Authority (EFSA) tahun 2011 menyatakan pemberian permen karet mengandung 1-2 gram xylitol tiga sampai lima kali sehari dikunyah minimal selama 5 menit setelah makan makanan yang mengandung karbohidrat, mempunyai efek menurunkan akumulasi plak, meningkatkan buffer saliva dan demineralisasi enamel, meningkatkan remineralisasi pada karies awal dan mengurangi jumlah Streptococcus mutans. ${ }^{11,22}$

\section{KESIMPULAN}

Berdasarkan penelitian yang dilakukan oleh peneliti terhadap perokok yang bekerja sebagai karyawan di Perusahaan Otomotif PT Astra Internasional Auto 2000 Tbk cabang Bypass Padang dapat disimpulkan sebagai berikut :

1. Rata-rata skor indeks plak sebelum mengunyah permen karet mengandung xylitol yaitu $37,9714 \pm 8,62106$ dengan kategori sedang (nilai skor plak antara 2140) dan rata-rata skor indeks plak sesudah mengunyah permen karet yaitu $15,2000 \pm 4,96340$ dengan kategori baik (nilai skor plak antara 0-20).

2. Rata-rata selisih penurunan indeks plak setengah dari angka rata-rata skor indeks plak awal dengan ratarata selisih penurunan nilai indeks plak sebelum dan sesudah perlakuan adalah $22,77143 \pm$ 9,49330 , dengan nilai $\mathrm{p}<0,05$.

3. Mengunyah permen karet mengandung xylitol efektif dalam membantu menurunkan skor indeks plak pada perokok.

\section{KEPUSTAKAAN}

1. Daliemunthe, S.H. 2008. Periodonsia. Edisi Revisi. Departemen Periodonsia FKG USU, Medan

2. Samaranayake L. 2006. Essential Microbiology for Dentistry. Churchill Livingstone :Elsevier Limited. p. 255 284

3. Putri M.H, dkk. 2011. Ilmu Pencegahan Penyakit Jaringan Keras Dan Jaringan Pendukung Gigi. EGC, Jakarta

4. Eley BM, Soory M, Mandson JD. 2010. Periodontics $.6^{\text {th }}$ edition.Saunder, London

5. Departemen Kesehatan RI. 2014. RisetKesehatan Dasar Nasional 
6. Ditjen Bina Upaya Kesehatan RI. 2012. Profil Data Kesehatan Indonesia Tahun 2011. Kementrian Kesehatan RI: 78-154

7. Felton A \& Alison C. 2009.Basic Guide to Oral Health Education and Promotion.KHL Printing, Malaysia

8. Putti D. 2008. Pengaruh Konsumsi Permen Karet yang mengandung Xylitol terhadap Pembentukkan Plak Gigi. Fakultas Kedokteran Universitas Diponegoro, Semarang. Website: http://www.eprints.undip.ac.id/24284/1/Put ti.pdf

9. Thaweboon S, et al. 2008. The Effec of Xylitol Gum on Mutans Streptococci in Saliva and Dental Plaque. Website : http://www.tm.mahidol.ac.th/seameo/2004/ 35_4/4 3-3307.pdf04/12/2008

10. Sroda R. 2005. Nutrition for a Healhty Mouth. Medik Book Store. United States America

11. Wilson M. 2009. Food Constituents and Oral Health. CRC Pres LLC, USA

12. Holgeston, P.L. 2007. Xylitol and it's Effect on Oral Ecology. Departement of odontology. Paediatric. Dentistry Fakulty of Medicine. Umea. Hal.16-20.

13. http://ash.org.uk/files/documents/ASH_59 8.pdfbiology-research-and-systemicconditions/use-ofpolyols-in-oral-biologyresearch

14. Rodian M, dkk. 2011. Effect of Chewing Gum Containing Sucrose, Xylitol and Probiotic to Saliva Characteristic. Dentika dental journal, 16

15. Burt B.A. 2006. The Use of Xylitol and Sorbitol Sweetened Chewing Gum in Caries Control. J Am Dent Assoc. 137,190

16. Natamiharja L.G. 2004. Indeks Periodontal dan Hubungannya Dengan Kebiasaan Merokok Pada Pegawai Dinas Pertanian Tingkat I Sumatera Utara. Dentika Dental Jurnal, 9

17. Pejcic O, dkk. 2007. Smoking And Periodontal Disease. A review. Medicine and Biology, 14

18. Hidayani, T.A \& Handajani. 2010. Effects of Smoking on the Salivary $\mathrm{pH}$ and
Volume in Adults and Elderly Males. Dentika Dental journal, 15

19. Flaherty, Julie. 2010. Is Once Enough. Tufts Journal. News and Information from Tufts University

20. Soesilo, Diana ; Santoso, Rinna Elyaawati ; Diyatri, Indeswati.2005. Peranan dalam mempertahankan $\mathrm{Ph}$ Saliva pada Proses Pencegahan karies. Majalah Kedokteran Gigi vol 38 no 1, FKG Airlangga hal.25-28

21. Yuliarsi Y.L,S. 2003. Efek Permen Karet yang Mengandung Xylitol dan Sorbitol Terhadap Plak Gigi dan Ginggivitis. JITEKGI FKGUPDM

22. Makinen, K.K. 2008. Properties of Xylitol. Hstory, Safety, and Dental

23. Ni Nyoman, G.S. 2011. Permen Karet Xylitol yang Dikunyah Selama 5 Menit Meningkatkan danMempertahankan $\mathrm{Ph}$ Saliva Selama 3 Jam. Tesis. Univ. Udayana, Denpasar 